\title{
Induction Death
}

National Cancer Institute

\section{Source}

National Cancer Institute. Induction Death. NCI Thesaurus. Code C121972.

Death of the patient due to the toxic side effects of induction therapy. 